\title{
Pembalikan Beban Pembuktian Sebagai Kebijakan Hukum Pidana Dalam Undang-Undang Tindak Pidana Korupsi
}

\author{
Oleh: Afrianto Sagita* \\ Dosen Tetap Fakultas Hukum Universitas 17 Agustus 1945 Jakarta \\ Jalan Sunter Permai, Tanjung Priok, Jakarta Utara
}

\begin{abstract}
Abstrak
Tujuan penelitian ini untuk menjelaskan urgensi pembalikan beban pembuktian sebagai kebijakan hukum pidana dalam undang-undang tindak pidana korupsi serta menjelaskan pengaturan pembalikan beban pembuktian sebagai upaya mendukung penanggulangan korupsi? Metode penelitian menggunakan metode penelitian yuridis normatif, bersumber dari penelitian kepustakaan atau Library re-search. Hasil penelitian ini dapat dijelaskan aturan-aturan hukum dalam rangka pemberantasan korupsi pun seharusnya selalu dikembangkan secara progresif sesuai perkembangan zaman, agar tidak ketinggalan dan kalah dengan modus-modus korupsi yang semakin mutakhir. Perlu adanya suatu formula baik dari perspektif teoritis, yuridis, filosofis dan praktik, mengenai bagaimana pembalikan beban pembuktian ini dapat diterapkan, baik ditataran kebijakan legislasi maupun aplikasi. Pembalikan beban pembuktian ke-seimbangan kemungkinan (balanced probability of principles), dapat dijadikan muatan utama perubahan Undang-Undang Pemberantasan Tindak Pidana Korupsi di Indonesia. Simpulan, pertama urgensi penerapan pembalikan beban menjadi sangat urgen untuk diterapkan dalam rangka mengungkap kebenaran menyangkut harta-harta terdakwa kasus korupsi yang patut diduga diperoleh dari hasil korupsi yang merugikan keuangan negara. Kedua, pengaturan mengenai pembalikan beban pembuktian dalam Undang-Undang Pembe-rantasan Tindak Pidana Korupsi telah mampu mendukung upaya penanggulangan korupsi di negeri ini, hanya saja masih terdapat kelemahan. Kelemahan tersebut mengenai pengaturan pembalikan beban pembuktian dalam UndangUndang Pemberantasan Tindak Pidana Korupsi yang bersifat terbatas atau berimbang, dalam hal ini terdakwa juga dibebankan melakukan pembuktian mengenai unsur-unsur kesalahan (schuld) dari terdakwa.
\end{abstract}

*Penulis korespondensi e-mail: afriantosagitamanurung@gmail.com 
Kata Kunci: Pembalikan Beban Pembuktian, Kebijakan Hukum Pidana, Tindak Pidana Korupsi

\begin{abstract}
The purpose of this study is to explain the urgency of reversing the burden of proof as a criminal law policy in corruption law and explain the regulation of reversing the burden of proof as an effort to support the eradication of corruption? The research method using normative juridical research method, sourced from library research or Library research. The results of this study can be explained the rules of law in order to eradicate corruption should always be developed prog-ressively according to the times, so as not to be left behind and lost with the corruption modes are getting updated. It is necessary to have a good formula from a theoretical, juridical, philosophical and practical perspective on how this reversal of evidentiary burden can be applied, both on legislation and application policy. The reversal of probabilistic probability of principles, can be the main charge of the amendment of the Anti-Corruption Eradication Act in Indonesia. In conclusion, first the urgency of the implementation of the load reversal becomes very urgent to be applied in order to reveal the truth about the treasures of accused corruption cases that are allegedly obtained from the corruption results that harm the state finances. Second, the regulation on reversing the burden of proof in the Corruption Eradication Act has been able to support the effort to overcome corruption in this country, but there are still weaknesses. The weaknesses concerning the provision of reversing the burden of proof in the Corruption Eradication Act which is limited or balanced, in this case the defendant is also charged to prove the element of error (schuld) of the defendant.
\end{abstract}

\title{
Keywords: Reversal of Burden of Evidence, Criminal Law Policy, Corruption Crime
}

\section{Pendahuluan}

Perubahan yang berlangsung di Indonesia sejak dikumandangkannya tuntutan reformasi oleh mahasiswa diiringi krisis yang menimbulkan kecemasan. Salah satu yang mencemaskan tersebut merajalela- nya koruptor yang mengakibatkan rusaknya perekonomian negara. Sampai saat ini, kasus korupsi dan penyalahgunaan kekuasaan masih tetap terjadi. Untuk memberantas dan mengatasinya diperlukan kesungguhan pemerintah (aparat pene- 
gak hukum). Hal itu karena tindak pidana korupsi dikategorikan sebagai tindak pidana yang luar biasa (extra ordinary crime).

Sebagai tindak pidana yang luar biasa, korupsi telah mengakar di dalam kehidupan masyarakat Indonesia. Bahkan kebiasaan korupsi telah menyusup dan menyatu kedalam sistem penyelenggaraan pemerintahan. Gurita korupsi semakin kuat melilit negeri ini. Segala upaya telah dilakukan dapat dikatakan gagal menahan dan memberantas laju korupsi. Sampai sejauh ini, praktik korupsi seperti tidak ada matinya. ${ }^{1}$

Korupsi merupakan perbuatan yang sangat tercela, terkutuk dan sangat dibenci oleh masyarakat internasional. Korupsi telah merusak sistem dan institusi sosial, ekonomi, mental dan citra aparatur negara. Indonesia mengalami kesulitan memberantas tindak pidana korupsi di seluruh instansi dan kegiatan pembangunan, dengan menggunakan begitu banyak variasi modus operandi. ${ }^{2}$

Perlu adanya penegasan ke-mbali bahwa tindak pidana korupsi di Indonesia sudah meluas di masyarakat. Perkembangannya pun terus meningkat dari tahun ke tahun, baik dari jumlah kasus maupun kerugian keuangan negara. Kualitas tindak pidana korupsi semakin sistematis memasuki seluruh aspek kehidupan masyarakat. Kondisi tersebut menjadi faktor utama penghambat keberhasilan mewujudkan masyarakat Indonesia adil dan makmur sebagaimana diamanatkan Undang-Undang Dasar Negara Republik Indonesia Tahun 1945. Kegagalan pemerintah dalam memberantas korupsi akan memperburuk citra pemerintah di mata masyarakat tercermin dalam bentuk ketidakpercayaan dan ketidakpatuhan masyarakat terhadap hukum. Apabila tidak ada perbaikan yang berarti maka kondisi tersebut akan membahayakan kelangsungan hidup bangsa. ${ }^{3}$ Romli Atmasasmita menekankan bahwa jika dikaji dari dampak negatif korupsi sangat merusak tatanan kehidupan karena perbuatan korupsi merupakan perampasan hak ekonomi dan hak sosial rakyat Indonesia. ${ }^{4}$ Hidayat Nurwahid pernah berkomentar koruptor adalah the real terrorists, sedangkan Kwik Kian Gie berargumen corruption is the roots of all evils. ${ }^{5}$ Senada dengan Hidayat Nurwahid dan Kwik Kian Gie, hal yang serupa juga pernah diutarakan Elwi Danil dalam disertasinya menyebutkan "bahwa di Indonesia, masalah korupsi sejak lama mewarnai berbagai aspek kehidupan masyarakat.

\footnotetext{
'Saldi Isra, Membinasakan Korupsi, dalam Harian Kompas 2 Maret 2011.

${ }^{2}$ Feri Wibisono, Menyongsong Era Baru Pemberantasan Tindak Pidana Korupsi, Media Hukum, Volume 1, Nomor 2, 2002, hlm. 70.

${ }^{3}$ Komisi Pemberantasan Korupsi, Buku I Rencana Stratejik KPK 2008-2011, Jakarta, 2008, hlm. 5-10.

${ }_{4}^{4}$ Lilik Mulyadi, Tindak Pidana Korupsi di Indonesia Normatif, Teoretis, Praktik dan Masalahnya, (Bandung: Alumni, 2007), hlm. 252. Lihat juga Romli Atmasasmita, Korupsi, Good Governance dan Komisi Anti Korupsi di Indonesia, (Jakarta: Badan Pembinaan Hukum Nasional Departemen Kehakiman dan HAM RI, 2002), hlm. 25.

${ }^{5}$ Denny Indrayana, Negeri Para Mafioso : Hukum di Sarang Penyamun, (Jakarta: Kompas, 2008), hlm. 9.
} 
Selama beberapa dasawarsa, fenomena itu telah menjadi suatu persoalan nasional yang sukar ditanggulangi. Bahkan secara sinis, ada komentar di sebuah jurnal asing mengulas kondisi korupsi di Indonesia dengan mengatakan, "corruption is way of life in Indonesia", yang berarti korupsi telah menjadi pandangan dan jalan kehidupan bangsa Indonesia ${ }^{6}$.

Selama tindak pidana korupsi merajalela maka pemerintahan tersebut akan sangat sulit untuk berkembang ke tahap fase pemerintahan negara maju. Edgargo Buscaglia dan Maria Dakolias ${ }^{7}$ sebagai mana dikutip oleh Denny Indrayana berpendapat di dalam tulisannya An Analysis of the Causes of Corruption in Judiciary:

"Corruption is an intrinsic part of the way the state operate in many countries, and it is impossible to remodel the state while it persist. Fighting corruption is therefore central to the process of reinvigorating the statefailure to confront it will obstruct reform initiates and prolong the high social and economic cost it brings" (Korupsi adalah bagian tak terpisahkan dari berjalannya suatu pemerintahan di banyak negara dan adalah mustahil memperbaiki negara tersebut selama korupsi masih ada. Dengan demikian perang melawan korupsi meru- pakan pusat masalah yang harus dipecahkan lebih dulu dalam proses perbaikan suatu negara. Karenanya kegagalan melawan korupsi akan menghalangi reformasi dan memperbesar biaya ekonomi dan sosial yang ditimbulkannya).

Pada tahun 2013 Transparency International kembali meluncurkan Corruption Perception Index (CPI) 2013 secara serentak di seluruh dunia. Survei ini mengingatkan, bahwa korupsi adalah fenomena global yang terjadi di seluruh dunia dengan tingkat kerawanan yang berbeda-beda. Krisis ekonomi global merupakan indikator konkrit tidak adanya transparansi dan akuntabilitas di sektor bisnis membuka peluang terhadap korupsi menyebabkan efek domino menghancurkan tata ekonomi dunia. Indeks pengukuran memiliki skala antara 0 (sangat korup) sampai dengan 100 (sangat bersih).

Skor Indonesia dalam CPI 2016 mencapai skala 37. Dengan skor ini, Indonesia menempati peringkat 90 negara terkorup di dunia berdasarkan pengukuran Corruption Perception Index (CPI) 2016 terhadap 176 negara di dunia. ${ }^{8}$ Skor ini dapat dibaca bahwa Indonesia masih dipandang rawan korupsi oleh para pelaku bisnis maupun pengamat atau analis negara.

${ }^{6}$ Elwi Danil, Fungsionalisasi Hukum Pidana dalam Penanggulangan Tindak Pidana Korupsi, Studi Tentang Urgensi Pembaharuan Hukum Pidana Terhadap Tindak Pidana Korupsi di Indonesia, Disertasi, Program Pascasarjana Fakultas Hukum Universitas Indonesia, Jakarta, 2001, hlm. 3.

${ }^{7}$ Denny Indrayana, Negeri Para...Op. Cit., hlm. 37-38.

${ }^{8} \mathrm{http} / / /$ www.transparency.org/news/feature/corruption_perception_index_2016, diakses tanggal 24 Maret 2017 jam 16:02 Wib. 
Skor Indonesia menunjukkan bahwa usaha pemberantasan korupsi masih jauh dari berhasil dan komitmen pemerintah terhadap terbentuknya tata kelola pemerintahan yang lebih baik harus dipertanyakan. Kondisi ini memberikan gambaran bahwa betapa korupsi di Indonesia sudah sangat kronis. $^{9}$ Dari perspektif internasional pada dasarnya korupsi merupakan salah satu kejahatan dalam klasifikasi white collar crime dan mempunyai akibat kompleksitas serta menjadi perhatian masyarakat Internasional. $^{10}$

Ban KiMoon (Sekretaris Jenderal PBB) menegaskan bahwa "Harta negara yang dikorupsi dapat membiayai program sosial dan infrastruktur publik. ${ }^{11}$

Kini yang terpenting adalah korupsidi suatu negara bukan lagi masalah negara itu sendiri tetapi sudah menjadi masalah atau kepedulian semua negara di dunia. ${ }^{12}$

Indriyanto Seno Adji mengatakan:

"Dalam konteks yang komprehensif, tidak dapat dipungkiri lagi bahwa korupsi merupakan white collar crime dengan perbuatan yang selalu mengalami dina- misasi modus operandinya dari segala sisi sehingga dikatakan sebagai invisible crime yang sangat sulit memperoleh prosedural pembuktiannya, karena sering kali memerlukan pendekatan sistem (systemic approach) terhadap pemberantasannya."13

Perbuatan korupsi dilakkan mulai dari "mark up" pengadaan barang dan jasa, pengadaan barang dan jasa yang menyalahi prosedur, penyalahgunaan wewenang, suap, pemberian atau penerimaan gratifikasi, penggunaan dana yang tidak sesuai dengan "posting" setiap anggaran mempunyai potensi merugikan keuangan dan perekonomian negara. ${ }^{14}$

Beberapa kasus korupsi merugikan negara dalam jumlah besar banyak yang belum terungkap, pada umumnya melibatkan pejabat negara dan penegak hukum yang punya kekuatan politik. Berikut ini peneliti sajikan beberapa contoh kasus korupsi yang sampai sekarang belum terungkap, misalnya kasus Bantuan Likuiditas Bank Indonesia (BLBI), aliran dana suap Bank Indonesia (BI) ke anggota DPR RI, kasus temuan rekening liar

\footnotetext{
${ }^{9}$ Alpiner Sinaga, Korupsi, Bias dan Strategi Penyidikan, (Jakarta: Markas Besar Kepolisian Negara Republik Indonesia, 2005), hIm. 1.

${ }^{10}$ A. Djoko Sumaryanto, Pembalikan Beban Pembuktian Tindak Pidana Korupsi dalam Rangka Pengembalian Kerugian Keuangan Negara, (Jakarta, Prestasi Pustakaraya, 2009), hlm. 1.

${ }^{11}$ Ibid.

${ }^{12}$ Ibid,Lihat juga M. Fadjroel Rachman, Rekor Koruptor, Harian Kompas, 20 September 2007, hlm. 6.

${ }^{13}$ Indryanto Seno Adji, Problematika Korupsi dan Antisipasinya Melalui Sistem Hukum Pidana, makalah disampaikan dalam seminar yang diadakan oleh puslitbang Kejaksaan Agung RI pada 21 Oktober 2003, hlm. 1.

${ }^{14}$ A. Djoko Sumaryanto, Pembalikan Beban...Op. Cit., hlm. 3. Lihat juga Nur Basuki Minarno, Pembuktian Gratifikasi dan Suap dalam Tindak Pidana Korupsi, Yuridika, Majalah Fakultas Hukum UNAIR, Volume 20, Nomor 2 Maret 2005.
} 
(5.192 rekening) di departemen pemerintah, kasus penyalahgunaan wewenang yang diduga dilakukan oleh mantan Ketua BPK Hadi Poernomo saat dirinya menjabat sebagai Direktur Jenderal Pajak, kasus pemberian FPJP dan bailout Bank Century.

Hampir dua abad yang lalu, Lord Acton (John Emerich Edward DalbergActon) dalam suratnya kepada Bishop Mandell Creighton menulis sebuah ungkapan yang menghubungkan antara "Korupsi" dengan "Kekuasaan," yakni: "Power tends to corrupt, and absolute power corrupts absolutely," bahwa "Kekuasaan cenderung untuk korupsi dan kekuasaan yang absolut cenderung korupsi absolut". ${ }^{15}$

Setidaknya hal tersebut tercermin dalam uraian beberapa contoh kasus korupsi yang telah dipaparkan di atas bahwa seseorang yang mempunyai jabatan, kewenangan dan kekuasaan, lebih dominan cenderung untuk melakukan perbuatan korupsi. Kasus korupsi yang mengakibatkan kerugian negara dalam jumlah besar justru lebih banyak dilakukan dalam lingkaran eksekutif, legislatif dan yudikatif. Lahirnya Undang-Undang Nomor 31 Tahun 1999 Juga Undang-Undang Nomor 20 Tahun 2001 tentang Tindak Pidana Korupsi bertujuan untuk menanggulangi dan memberantas tindak pidana korupsi serta bertujuan untuk efisiensi dan efektif mungkin dapat mengurangi dan mengembalikan kerugian keuangan negara yang ditimbulkan oleh perbuatan korupsi tersebut. UndangUndang Nomor 31 Tahun 1999 Jo Undang-Undang Nomor 20 Tahun 2001 tentang Tindak Pidana Korupsi menerapkan pembalikan be-ban pembuktian yang bersifat terbatas dan berimbang. Dalam artian, bahwa terdakwa mempunyai hak untuk membuktikan ia tidak melakukan tindak pidana korupsi dan wajib memberikan keterangan tentang seluruh harta bendanya dan harta benda istri atau suami, anak, dan harta benda setiap orang atau korporasi yang diduga mempunyai hubungan dengan perkara yang bersangkutan dan penuntut umum tetap berkewajiban membuktikan dakwaannya.

Elwi Danil berpendapat bahwa: "Pembalikan beban pembuktian atau "omkering van de bewisjlast" (the reversal of the burden of proof), sering juga disebut sistem pembuktian terbalik, secara umum dapat dipahami sebagai suatu sistem yang meletakkan beban pembuktian di tangan terdakwa untuk membuktikan bahwa ia tidak bersalah melakukan tindak pidana yang didakwakan kepadanya". ${ }^{16}$

Dalam hal terdakwa tidak berhasil membuktikan bahwa ia tidak bersalah maka ia dinyatakan bersalah melakukan tindak pidana.

${ }^{15}$ Ermansjah Djaja, Tipologi Tindak Pidana Korupsi di Indonesia, (Bandung: Mandar Maju, 2010), hlm. 1. Lihat juga Romli Atmasasmita, Sekitar Masalah Korupsi Aspek Nasional dan Aspek Internasional, (Bandung: Mandar Maju, 2004), hlm. 38.

${ }^{16}$ Maria Silvya E. Wangga ${ }^{1}$ Elwi Danil, Korupsi: Konsep, Tindak Pidana, dan Pemberantasannya, (Jakarta: Rajagrafindo Persada, 2012), hlm. 201. 
Sementara penuntut umum dibebaskan dari kewajiban pem buktian. ${ }^{17}$ Hanya karena alasan pem-buktian yang sulit, banyak korup-tor di Indonesia tidak tersentuh hukum pidana. Mereka cenderung berlindung di balik asas praduga tak bersalah bahkan dapat dikata-kan "dimanjakan" oleh asas hu-kum pidana itu sendiri, sehingga kepentingan masyarakat banyak terabaikan. ${ }^{18}$ Oleh karena modus operandi dari kasus korupsi yang semakin canggih dan modern, sering dikategorikan sebagai invi-sible crime yang sangat sulit memperoleh prosedural pembuktian-nya. Pengimplementasian pemb-alikan beban pembuktian tersebut diharapkan mampu mengeliminasi tingkat kesulitan pembuktian dalam pemberantasan tindak pidana korupsi. ${ }^{19}$

Melalui proses pembuktian inilah ditentukan kekuatan pembuktian dari setiap alat bukti akan menjadikan seorang terdakwa dibebaskan (vrijspraak), dilepaskan dari segala tuntutan (onstlag van alle rechtsvervolging), atau dipidana. Di tengah kebuntuan proses hukum pembuktian untuk menghadapkan para pelaku korupsi kehadapan proses peradilan pidana, penerapan pembalikan beban pembuktian oleh sementara ahli hukum diyakini mampu mengeliminasi tingkat kesulitan pembuktian. ${ }^{20}$

Usaha memberantas korupsi sudah menjadi masalah global, bukan lagi nasional atau regional. Gejala korupsi ada pada setiap negara terutama yang sedang membangun, sudah hampir menjadi conditio sine qua non. Ada usaha terutama karena desakan rakyat agar korupsi dibabat habis kalau perlu dengan hukum darurat, seperti pidana berat, pembebasan penanganan korupsi dari instansi normal ke suatu badan independen yang dijamin integritasnya, dan sistem pembalikan beban pembuktian. ${ }^{21}$

Korupsi tidak sekedar pemi-danaan saja, tetapi bagaimana ke-bijakan hukum pidana menghadapi invisible crime tersebut. Perhatian dan peran hukum pidana terhadap perbuatan yang masuk kategori "tindak pidana korupsi," baik yang eksplisitas ada maupun tidak ada pengaturannya dalam hukum pidana positif di Indonesia. ${ }^{22}$ Bila dikaji dari perspektif kebijakan hukum pidana, eksistensi pembalikan beban pembuktian mengandung prevensi khusus bagi tindak pidana korupsi yang dikategorikan sebagai extra ordinary crime yang juga membutuhkan extra ordinary enforcement dan extra ordinary measures.

\footnotetext{
${ }^{17}$ Ibid, Lihat juga Oemar Seno Adji dalam Albert Hasibuan, Guru Besar Berbicara tentang Hukum, (Bandung: Alumni, 1985), hlm. 35.

${ }^{18} \mathrm{lbid}$, hlm. 216-217.

${ }^{19} \mathrm{lbid}, \mathrm{hlm} .193$.

${ }^{20} \mathrm{lbid}$, hlm. 201.

${ }^{21}$ Andi Hamzah, Perbandingan Pemberantasan Korupsi di Berbagai Negara, (Jakarta: Sinar Grafika 2008), hlm. V.

${ }_{22}^{22}$ Indriyanto Seno Adji, Korupsi Kebijakan Aparatur Negara \& Hukum Pidana, (Jakarta: Diadit Media, 2009), hlm. 315.
} 
Penelitian sejenis pernah diteliti oleh penulis lain, tetapi substansinya berbeda dengan penelitian ini. Maria Silvya E. Wangga pernah meneliti tentang mekanisme pembalikan beban pembuktian tindak pidana pencucian uang. Dalam penelitiannya menyimpulkan penerapan prinsip pembalikan beban pembuktian dalam tindak pidana pencucian hanya dilakukan oleh terdakwa atas harta kekayaan yang diduga diperoleh dari tindak pidana korupsi, penyuapan, narkotika, psikotropika, penyelundupan tenaga kerja, penyelundupan migrant, di bidang perbankan, di bidang pasar modal, di bidang perasuransiaan, kepabeanan, cukai, perdagangan manusia, perdagangan senjata gelap, terorisme, penculikan, pencurian, penggelapan, penipuan, pemalsuan uang, perjudian, prostitusi, di bidang perpajakan, di bidang kehutanan, di bidang lingkungan hidup, di bidang kelautan dan perikanan atau tindak pidana lain yang diancam pidana penjara 4 (empat) tahun atau lebih. Untuk mendukung penerapkan prinsip pembalikan beban pembuktian dalam tindak pidana pencucian uang perlu menerapkan metode penelusuran dan pengungkapan harta kekayaan serta didukung oleh data-data berupa laporan harta kekayaan pejabat negara sebelum, selama dan sesudah menjabat sehingga dapat membuk- tikan semua rumusan unsur tindak pidana pencucian uang. ${ }^{23}$

Mulyanto pernah meneliti tentang praktik pembatasan pembalikan beban pembuktian dalam pengadilan tipikor (studi pada perkara korupsi RAPBD Kota Semarang di Pengadilan Tipikor Kota Semarang). Dalam penelitiannya menyimpulkan bahwa penerapan sistem pembuktian terbalik dirasakan sangat efektif dalam menangani tindak pidana korupsi, paling tidak pembuktian tersebut untuk meminimalisir adanya kerugian negara akibat tindak pidana korupsi. Sebab pada prinsipnya tujuan dari pembuktian terbalik untuk melacak keuangan negara yang dialihkan menjadi milik pribadi. Perkara korupsi yang terjadi di Pengadilan Tipikor Semarang, pada dasarnya tidak merugikan keuangan negara, karena masuk unsur tindak pidana suap. Adapun tidak terjadinya kerugian negara dan tergolong sebagai salah satu syarat untuk dilakukannya pembuktian terbalik, namun karena masuk perkara suap yang tidak merugikan keuangan negara maka pembuktian terbalik dalam persidangan tidak dilakukan. ${ }^{24}$

Wahyu Wiriadinata menulis tentang korupsi dan pembalikan beban pembuktian. Dalam penelitiannya menyimpulkan untuk mencegah dan mengatasi tindak pidana korupsi di Indonesi aserta untuk

\footnotetext{
${ }^{23}$ Maria Silvya E. Wangga, Mekanisme Pembalikan Beban Pembuktian Tindak Pidana Pencucian Uang Adil, Jurnal Jurnal Hukum, Volume 3, Nomor 2, 2015, hlm. 351.

${ }^{24}$ Mulyanto, Praktik Pembatasan Pembalikan Beban Pembuktian Dalam Pengadilan Tipikor (Studi Pada Perkara Korupsi RAPBD Kota Semarang di Pengadilan Tipikor Kota Semarang), JurnalJurisprudence, Volume 6, Nomor 2, September 2016, hlm. 124.
} 
menghilangkan tindak pidana korupsi, paling tidak mengurangi kualitas maupun kuantitasnya maka tidak cukup dilakukan pendekatan secara yuridis, tapi juga pendekatan sosiologis dan politis. Khususnyadalam penanganan tindak pi-dana korupsi sistem hukum acara pidana untuk penanganan dan penyelesaiannya harus seefektif mungkin diterapkan. Tidak cukup dengan menggunakan sistem pembuktian yang konvensional, tetapi nampaknya harus digunakan sistem pembuktian terbalik murni. Namun, demikian pemberlakuan sistem pembuktian terbalik murni - pure reversalborden of proof akan menimbulkan pelanggaran terhadap asas hukum praduga tidak bersalah, nonself incrimination, pelanggaran terhadap hak asasi manusia,dan hak tidak untuk bungkam, juga akan menimbulkan chaos birokrasi. ${ }^{25}$

Bila setelah penelitian terdahulu tersebut tidak sama kajian-nya dengan substansinya dengan permasalahan penelitian ini, sehingga penelitian ini akan menghasilkan suatu kebaruan (novelty). Adapun permasalahan penelitian ini, sehingga penelitian ini akan menghasilkan suatu kebaruan (novelty). Adapun permasalahan penelitian ini, Pertama, bagaimana urgensi pembalikan beban pembuktian sebagai kebijakan hukum pidana dalam unda- ngundang tindak pidana korupsi? Kedua, bagaimana pengaturan pembalikan beban pembuktian sebagai upaya mendukung penanggulangan korupsi? Hasil yang di harapkan dari penelitian ini menjelaskan urgensi pembalikan beban pembuktian sebagai kebijakan hukum pidana dalam undang-undang tindak pidana korupsi. Selain itu, penelitian ini diharapkan dapat dijadikan pengembangan ilmu pengetahuan khususnya hukum pidana.

Dilihat dari objek yang akan diteliti maka penelitian ini termasuk ke dalam "penelitian hukum," yaitu merupakan suatu kegiatan ilmiah didasarkan pada metode, sistematika dan pemikiran tertentu bertujuan untuk mempelajari satu atau beberapa gejala hukum tertentu dengan jalan menganalisisnya. ${ }^{26}$

Kegiatan penelitian hukum akan dilakukan dengan cara menggunakan pendekatan yuridis normatif, yaitu dilakukan dengan cara meneliti bahan pustaka atau data sekunder yang berhubungan dengan rumusan permasalahan yang telah ditetapkan. ${ }^{27}$ Penelitian ini bersifat deskrip-tif, yaitu penelitian yang dilakukan untuk menguraikan objek penelitiannya atau penelitian yang bertujuan untuk melukiskan tentang sesuatu hal di daerah tertentu dan pada saat tertentu. ${ }^{28}$

\footnotetext{
${ }^{25}$ Wahyu Wiriadinata, Korupsi dan Pembalikan Beban Pembuktian, Jurnal Konstitusi, Volume 9, Nomor 2, Juni 2012, hlm. 330.

${ }^{26}$ Soerjono Soekanto, PengantarPenelitianHukum, PenerbitUniversitas Indonesia, (Jakarta: UI-Press, 2006), hlm. 43.

${ }^{27}$ Soerjono Soekanto dan Sri Mamudji, Penelitian Hukum Normatif (Suatu Tinjauan Singkat), (Jakarta: Raja Grafindo Persada, 2009), hlm. 13-14.

8.

${ }^{28}$ Bambang Waluyo, PenelitianHukumdalamPraktik, (Jakarta: SinarGrafika, 2002), hlm.
} 


\section{Metode Penelitian}

Bahan hukum penelitian ini bersumber dari penelitian kepustakaan atau library research. Dalam penelitian kepustakaan data yang diperoleh berupa data sekunder, yakni data yang telah terolah atau tersusun, ${ }^{29}$

Meliputi bahan hukum primer, bahan hukum sekunder, dan bahan hukum tersier.

Teknik pengumpulan bahan hukum melalui penelitian kepustakaan (library research) untuk mendapatkan konsepsi teori atau doktrin, pendapat atau pemikiran konseptual dan penelitian terdahulu yang berhubungan dengan obyek telahan penelitian ini yang dapat berupa peraturan perundang - undangan, buku, tulisan ilmiah dan karya-karya ilmiah lainnya. Pada tahap awal pengumpulan data, dilakukan inventarisir terhadap seluruh data dan dokumen yang relevan dengan topik pembahasan. Selanjutnya dilakukan pengkat egorian data-data tersebut berdasarkan rumusan masalah yang telah ditetapkan.

Data yang diperoleh dikelompokkan dan disusun secara sistematis dan selanjutnya dianalisis secara analisis kualitatif, yaitu analisis berupa kalimat dan uraian. ${ }^{30}$

Metode yang digunakan anali-sis yuridis, yaitu analisis mendasar-kan pada teori-teori, konsep dan peraturan perundang-undangan.
Setelah itu, data yang diperoleh disusun secara sistematis dan untuk selanjutnya analisis kualitatif dipakai untuk mencapai penjelasan yang dibahas.

\section{Pembahasan}

Urgensi Pembalikan Beban Pembuktian Sebagai Kebijakan Hukum Pidana Dalam UndangUndang Tindak Pidana Korupsi

Dalam penjelasan umum Undang-Undang Nomor 30 Tahun 2002 tentang KPK disebutkan bahwa tindak pidana korupsi juga merupakan pelanggaran terhadap hak-hak sosial dan hak-hak ekonomi masyarakat, dan karena itu semua tindak pidana korupsi tidak lagi dapat digolongkan sebagai kejahatan biasa (ordinary crime), melainkan telah menjadi suatu kejahatan luar biasa (extra ordinary crime). Begitu pun dalam upaya pemberantasannya tidak lagi dapat dilakukan secara biasa, tetapi dituntut cara-cara yang luar biasa. Permasalahan tindak pidana korupsi merupakan suatu permasalahan yang kompleks.

Pandangan Peter Eigen, sampai batas-batas tertentu, korupsi tidak saja mengancam lingkungan hidup, hak asasi manusia, dan lembaga-lembaga demokrasi, tetapi juga menghambat pembangunan dan memperparah kemiskinan jutaan orang di seluruh dunia. ${ }^{31}$

\footnotetext{
${ }^{29}$ Soerjono Soekanto, PengantarPenelitian...Op. Cit., hlm. 12.

${ }^{30}$ Achmad Ali, Menjelajahi Kajian Empiris Terhadap Hukum, (Jakarta: Yasrif Watampone, 2008), hlm. 188.

${ }^{31}$ Saldi Isra, Pemberantasan Korupsi: Beberapa Warisan Islam yang Dipraktikkan di Indonesia, Jurnal Konstitusi, Pusako Universitas Andalas, Volume III, Nomor 2, 2010, hlm. 155.
} 
Romli Atmasasmita ${ }^{32}$ sebagai mana yang dikutip Saldi Isra menambahkan bahwa perkembangan korupsi telah mengancam stabilitas dan keamanan nasional dan internasional, melemahkan institusi dan nilai-nilai demokrasi, keadilan, serta membahayakan pembangunan berkelanjutan dan penegakan hukum.

Ancaman serta dampak yang ditimbulkan korupsi, memasuki abad ke-21, masyarakat Internasional sepakat membangun kerjasama dalam memberantas korupsi. Melalui Ad hoc Committee For The Negotiation of The United Nations Conventions Against Corruption terhitung sejak 1 Oktober 2003, lebih dari 107 negara telah menyetujui korupsi sebagai sebuah transnational crime. Indonesia merupakan salah satu negara peserta yang ikut menyetujui Conventions Against Corruption yang diselenggarakan di Wina tersebut. ${ }^{33}$ Sejak dibentuk pada tahun 2002 berdasarkan Undang-Undang Nomor 30 Tahun 2002 KPK menjelma menjadi lem- baga "superbody" memiliki kewenangan lebih besar dan prestisius bila dibandingkan dengan yang dimiliki oleh aparat penegak hukum lain. KPK diberikan kewenangan "ekstra teritorial" untuk melakukan supervisi terhadap instansi yang berwenang melakukan pemberantasan tindak pidana korupsi yang sudah ada sebelumnya ${ }^{34}$ dan dalam keadaan tertentu ${ }^{35}$ dapat mengambil alih tugas dan wewenang penyelidikan, penyidikan, dan penuntutan yang sedang dilaksanakan oleh kepolisian dan atau kejaksaan. Jika dilihat ke dalam ketentuan UndangUndang Pemberantasan Tindak Pidana Korupsi diintroduksi sanksi pidana mati bagi pelaku tindak pidana korupsi yang dilakukan terhadap dana-dana yang diperuntukkan bagi penanggulangan keadaan bahaya, bencana alam nasional, penanggulangan akibat kerusu-han sosial yang meluas, penanggulangan krisis ekonomi dan moneter, dan pengulangan tindak pidana korupsi.

\footnotetext{
${ }^{32}$ Ibid

${ }^{33}$ Romli Atmasasmita, Sekitar Masalah Korupsi Aspek Nasional dan Aspek Internasional, (Bandung Mandar Maju, 2004), hlm. V.

${ }^{34}$ Selain Kepolisian dan Kejaksaan, yang dimaksud dengan " instansi yang berwenang" termasuk Badan Pemeriksa Keuangan, Badan Pengawas Keuangan dan Pembangunan, Komisi Pemeriksa Kekayaan Penyelenggara Negara, inspektorat pada Departemen atau Lembaga Pemerintah Non-Departemen.

${ }^{35}$ Dalam melaksanakan wewenang supervisi, KPK berwenang juga mengambil alih penyidikan atau penuntutan terhadap pelaku tindak pidana korupsi yang sedang dilakukan oleh kepolisian atau kejaksaan. dengan alasan: (1) Laporan masyarakat mengenai tindak pidana korupsi tidak ditindaklanjuti; (2) Proses penanganan tindak pidana korupsi secara berlarut-larut atau tertunda-tunda tanpa alasan yang dapat dipertanggungjawabkan; (3) Penanganan tindak pidana korupsi ditujukan untuk melindungi pelaku tindak pidana korupsi yang se-sungguhnya; (4) Penanganan tindak pidana korupsi mengandung unsur korupsi; (5) Hambatan penanganan tindak pidana korupsi karena campur tangan dari eksekutif, yudikatif, atau legislatif; atau (6) Keadaan lain yang menurut pertimbangan kepolisian atau kejaksaan, penanganan tindak pidana korupsi sulit dilaksanakan secara baik dan dapat dipertanggungjawabkan.
} 
Dengan adanya pengayaan sanksi pidana di dalam undangundang pemberantasan tindak pidana korupsi merupakan suatu indikasi diakuinya korupsi sebagai musuh besar bersama bangsa ini.

Istilah sistem Pembuktian Ter-balik telah dikenal oleh masyarakat sebagai bahasa yang dengan mudah dapat dicerna dan dikenal sebagai salah satu solusi dalam pemberantasan korupsi. Namun, menurut Andi Hamzah penggunaan istilah sistem pembuktian terbalik kurang tepat karena tanpa meletakkan kata "beban" makna yang timbul akan berbeda. Pembuktian terbalik tanpa istilah "beban" dapat diartikan tidak adanya beban pembuktian dari terdakwa, sehingga bisa saja ditafsirkan secara harafiah yang hanya melihat pergeseran tata urutan alat bukti saja, oleh sebab itu jika dilakukan pendekatan secara gramatikal maka reversal burden of proof jika diartikan secara bebas menjadi "pembalikan beban pembuktian." ${ }^{\text {" }}$ Sebagai asas universal, memang akan menjadi pengertian yang bias apabila diterjemahkan sebagai "pembuktian terbalik". Disini ada suatu beban pembuktian yang diletakkan kepada salah satu pihak, yang univ-ersalistis terletak pada penuntut umum, namun mengingat ad-anya sifat kekhususan yang sangat mendesak, beban pembuktian itu diletakkan tidak lagi pada penuntut umum, tetapi kepada terdakwa. ${ }^{37}$ Proses pembalikan beban dalam pembuktian inilah yang kemudian dikenal sebagai "pembalikan beban pembuktian". Pembalikan beban pembuktian diatur dalam Undang-Undang Pemberantasan Tindak Pidana Korupsi. Hukum harus dilaksanakan dan ditegakkan dan dalam penegakan hukum haruslah mengedepankan unsur formalitas hukum yang sesuai dengan asas legalitas. $^{38}$ diterapkannya hukum dalam hal terjadi peristiwa konkret.

Bagaimana hukumnya itulah yang harus berlaku, pada dasarnya tidak boleh menyimpang: fiat justitia et pereat mundus, meski-pun dunia ini runtuh hukum harus ditegakkan, ${ }^{39}$ sehingga pemberantasan korupsi di negeri ini tidak hanya sekedar ilusi.

Pada dasarnya, dengan dianutnya suatu pembalikan beban pembuktian secara murni akan menyebabkan beralihnya asas praduga tidak bersalah (presumption of innocent) menjadi asas praduga bersalah (presumption of guilt). Dengan dimensi yang demikian maka suatu pembalikan beban pembuktian secara murni yang dapat menyebabkan beralihnya asas praduga tidak bersalah (presumption of innocent) relatif

${ }^{36}$ Indriyanto Seno Adji, Korupsi dan...Op.Cit., hlm. 277. Lihat juga Andi Hamzah, Ide yang Melatar Belakangi Pembalikan Beban Pembuktian, Makalah pada Seminar Nasional Debat Publik Tentang Pembalikan Beban Pembuktian, 11 Juli 2001 di Universitas Trisakti.

${ }^{37} \mathrm{lbid}$, hlm. 278.

${ }^{38}$ Pengertian asas legalitas adalah: "tiada perbuatan dapat dipidana kecuali atas dasar kekuatan ketentuan pidana menurut undang-undang yang sudah ada terlebih dahulu" Lihat Eddy O.S Hiariej, Asas Legalitas dan Penemuan Hukum Dalam Hukum Pidana, (Jakarta: Erlangga, 2009), hlm. 124

${ }^{39}$ Sudikno Mertokusumo dan A. Pitlo, Bab-bab Tentang Penemuan Hukum, (Bandung, Citra Aditya Bakti, 1993), hlm. 1-2. 
cenderung dianggap sebagai pengingkaran terhadap asas yang telah berlaku secara universal tersebut. Praduga tidak bersalah merupakan asas fundamental dalam suatu negara hukum, pengingkaran atau minimalisasi asas ini merupakan suatu pelanggaran dan tidak dapat dibenarkan dengan alasan apapun. Indriyanto Seno Adji dengan tegas mengatakan bahwa, "terdakwa tidak pernah dibebankan untuk membuktikan kesalahannya, bahkan tidak pernah diwajibkan untuk mempersalahkan dirinya sendiri (nonselfincrimination). Lebih jauh lagi disebutkan bahwa terdakwa memiliki hak yang dinamakan "the right to remain silent" (hak untuk diam). Semua prinsip perlindungan dan penghargaan terhadap Hak Asasi Manusia (HAM) terdakwa yang tidak dapat dikurangi sedikit pun dan dengan alasan apapun juga (non derogable right)". ${ }^{0}$ Meskipun demikian, ada pula sebagian kalangan yang berpen dapat bahwa penerapan pembali kan beban pembuktian tidak sampai jatuh kepada "abrogation" dari hak-hak asasi yang dimiliki seorang terdakwa, melainkan hanya pengurangan (diminution) dari pada hak-hak asasi tersebut. Pengurangan (diminution) ini diperkenankan dalam penanganan terhadap tindak pidana tertentu seperti tindak pidana ko- rupsi oleh karena alasan untuk menyelamatkan bahaya yang dapat ditimbulkan oleh korupsi yang merupakan suatu kejahatan luar biasa (extraordinary crime).

Penerapan pembalikan beban pembuktian dianggap se-bagai suatu kekhususan dari ketentuan KUHAP, sehingga be-rlaku asas lex specialis derogat legi generalis. ${ }^{41}$ Alasan lainnya menyatakan penerapan pembalikan beban pembuktian merupakan salah satu sarana yang dapat ditempuh untuk memberantas tindak pidana korupsi yang sudah mengakar di Indonesia. Hal ini sesuai dengan tujuan hukum menurut Jeremy Bentham dalam bukunya Introduction to the Morals and Legislation, yaitu bahwa hukum bertujuan untuk mewujudkan se mata-mata berfaedah bagi semua orang. Dikarenakan apa yang berfaedah bagi banyak orang mungkin saja merugikan orang lain maka tujuan hukum adalah menjamin kebahagiaan bagi sebanyak-banyaknya orang. Penerapan pembalikan beban pembuktian memang disatu pihak akan merugikan terdakwa, karena haknya akan dikurangi atau kurang terlindungi, tetapi di lain pihak hal ini akan membawa kebahagiaan atau kemanfaatan bagi orang banyak, karena dapat mengurangi tindak pidana korupsi yang telah banyak merugikan negara. ${ }^{42}$

\footnotetext{
${ }^{40}$ Indryanto Seno Adji, Korupsi Kebijakan...Op. Cit., hIm. 333.

${ }^{41}$ Mohammad Zamroni, "Telaah Progresif: Implementasi Asas Pembuktian Terbalik (Reversed Onus) Terhadap Tindak Pidana Korupsi", Jurnal Legislasi Indonesia, Volume 8, Nomor 2, Juni 2011, hlm. 294, Lihat juga Sudarto, Hukum dan Hukum Pidana, (Bandung: Alumni, 1986), hlm. 141-142.

${ }^{42}$ lbid.
} 
Namun, anggapan di atas sebenarnya lemah karena secara universal tidak dikenal pembalikan beban pembuktian yang bersifat umum. Muladi mengingatkan bahwa dimensi asas pembalikan beban pembuktian hendaknya dilakukan secara hati-hati dan selektif karena sangat rawan terhadap pelanggaran HAM dan dilakukan dalam rangka "proceeding". Aspek ini dinyatakan, bahwa ${ }^{43}$ " secara universal tidak dikenal pembuktian terbalik yang bersifat umum, sebab hal ini sangat rawan terhadap pelanggaran HAM. Seorang tidak dapat dituduh melakukan korupsi di luar "proceeding" (dalam kedudukan sebagai terdakwa), hanya karena dia tidak dapat membuktikan asal usul kekayaannya. Dengan demikian sekalipun dalam hal ini ber-laku asas praduga bersalah (presumption of guilt) dalam bentuk "presumption of corruption", tetapibeban pembuktian terbalik tersebutharus dalam kerangka "proceeding" kasus atau tindak pidana tertentu yang sedang diadili berdasarkan undang-undang pemberantasan tindak pidana korupsi yang berlaku (presumption of corruption in certain cases). Tanpa adanya pembatasan semacam ini sistem pembuktian terbalik pasti akan menimbulkan apa yang dinamakan "miscarriage of justice yang bersifat krimonogen" Eksistensi pembalikan beban pembuktian merupakan suatu hal yang dilematis, Elwi Danil ${ }^{44}$ mengatakan lebih detail bahwa "persoalan yang muncul berkaitan dengan jaminan dan perlindungan hak asasi manusia adalah menyangkut adanya "criminal policy" untuk menerapkan sistem pembalikan beban pembuktian dalam pemberantasan tindak pidana korupsi." Dengan dianutnya sistem tersebut yang di dalamnya terkandung "presumption of guilt" cenderung dianggap sebagai pengingkaran terhadap asasasas yang bersifat universal, di antaranya asas praduga tak bersalah. Lantas persoalannya, sejauh mana sistem itu diperkenankan, sehingga tidak dilihat semata-mata sebagai suatu pelanggaran asas, melainkan hanyalah merupakan suatu asas yang dengan sangat terpaksa dilakukan.

Pembalikan beban pembuktian dalam Undang-Undang Pemberantasan Tindak Pidana Korupsi, menurut sistem hukum pidana Indonesia merupakan suatu bentuk pembaruan hukum pidana. Barda Nawawi Arif melihat adanya upaya pem-baruan hukum pidana (penal reform) yang pada hakekatnya merupakan bagian dan terkait erat dengan law enforcement policy, criminal policy, dan social policy. Aspek ini dapat diartikan bahwa pembaruan hukum pidana merupakan bagian dari memperbarui subta nsi hukum, bagian kebijakan memberantas kejahatan dalam rangka

\footnotetext{
${ }^{43}$ Muladi, Sistem Pembuktian Terbalik (Omkering van Bewijslast atau Reverse Burden of Proof atau Shifting Burden of Proof), Majalah Varia Peradilan, Volume 2, Nomor 1, Desember 2002, hlm. 121-122.

${ }^{44}$ Lilik Mulyadi, Alternatif Pengaturan Pembalikan Beban Pembuktian Dalam UndangUndang Pemberantasan Tindak Pidana Korupsi Indonesia Pasca Ratifikasi Konvensi Perserikatan Bangsa-Bangsa Anti Korupsi 2003 (KAK 2003), Artikel Hukum, Malang, 7 Oktober 2008, hlm. 20.
} 
perlindungan masyarakat sebagai social defence dan social welfares serta penegakan hukum. ${ }^{45}$

Dari pemaparan di atas, dapatlah ditarik sebuah kesimpulan awal bahwa di kalangan para pakar hukum sendiri terlihat adanya pandangan pro dan kontra mengenai penerapan pembalikan beban pembuktian, yang kontra berpendapat bahwa secara universal penerapan pembalikan beban pembuktian memang akan bersinggungan langsung dengan HAM terdakwa disebabkan penerapannya akan menghilangkan eksistensi asas praduga tidak bersalah (presumption of innocent) dan hak-hak prinsipel terdakwa. Hal ini akan terjadi apabila penerapannya tidak dilakukan secara hati-hati dan selektif, karena sebagaimana yang ditegaskan.

Indriyanto Seno Adji, perlindungan dan penghargaan terhadap HAM terdakwa tidak dapat dikurangi sedikit pun dan dengan alasan apapun (nonderogableright). Namun, disisi lain yang setuju dengan penerapan pembalikan beban pembuktian ini berpendapat bahwa penerapan pembalikan beban pembuktian ini jangan hanya dilihat semata-mata sebagai pelanggaran asas, melainkan hanyalah merupakan suatu asas yang dengan sangat terpaksa dilakukan.

Penerapan pembalikan be-ban pembuktian menjadi sangat urgen untuk diterapkan dalam rang-ka mengungkap kebenaran menyangkut harta-harta terdak-wa kasus korupsi yang patut diduga diperoleh dari hasil korupsi yang merugikan keuangan negara. Tentunya penerapannya harus dilakukan secara hati-hati dan selektif, agar tidak bersinggungan langsung dengan HAM terdakwa. Namun, sebelumnya perlu dibahas terlebih dahulu eksistensi pengaturan mengenai pembalikan beban pembuktian dalam UndangUndang Pemberantasan Tindak Pidana Korupsi.

\section{Pengaturan Pembalikan Beban Pembuktian Sebagai Upaya Men- dukung Penanggulangan Korupsi}

Sebagaimana telah dijelaskan sebelumnya, bahwa penerapan pembalikan beban pembuktian secara murni dapat menyebabkan beralihnya asas praduga tidak bersalah (presumption ofinnocent) menjadi asas praduga bersalah (presumption of guilt) dan relatif cenderung dianggap sebagai pengingkaran terhadap asasasas yang telah berlaku secara universal. Berbeda halnya dengan "teori pembalikan beban pembuktian keseimbangan kemungkinan (balanced probability of principles)" dari Oliver Stolpe, yang mengedepankan keseimbangan secara proporsional antara perlindungan kemerdekaan individu di satu sisi dan perampasan hak individu

\footnotetext{
${ }^{45}$ Barda Nawawi Arief, Pembaharuan Hukum Pidana Dalam Perspektif Kajian Perbandingan, (Bandung: Citra Aditya Bakti, 2005), hlm. 3-4.
} 
yang bersangkutan atas harta kekayaan milik pelaku yang diduga kuat berasal dari korupsi disisi lainnya. ${ }^{46}$

Asumsi dasar teori ini, menem patkan pelaku tindak pidana korupsi terhadap perbuatan atau kesalahan yang diduga dilakukannya sesuai dengan tindak pidana korupsi pokok yang didakwakan oleh penuntut umum dengan tidak boleh dipergunakan pembalikan beban pembuktian melainkan tetap berdasarkan pembuktian secara negatif menurut undang-undang (negatief wettelijke bewijs theorie). Oleh karena perlindungan terhadap hak individu ditempatkan paling tinggi terhadap perampasan kemerdekaan seseorang. Konsekuensi logisnya, aspek ini tetap mengkedepankan dimensi HAM, aspek ketentuan hukum acara pidana khususnya mengenai asas praduga tidak bersalah (presumption of innocent), dan ketentuan terdakwa tidak dibebankan kewajiban pembuktian terhadap unsur kesalahan (schuld) terdakwa.

Kedudukan hak asasi pelaku tindak pidana korupsi ditempatkan dalam kedudukan (level) yang paling tinggi dengan mempergunakan "teori probabilitas berimbang yang sangat tinggi (highest balanced probability of principles)" yang tetap mempergunakan pembuktian secara negatif menurut undang-undang (negatief wettelijke bewijs theorie).
Pembalikan beban pembuktian dapat dilakukan terhadap asal usul mengenai kepemilikan harta kekayaan pelaku yang diduga berasal dari tindak pidana korupsi sehingga tidak berdasarkan pada pembuktian secara negatif menurut undang-undang (negatief wettelijke bewijs theorie). Pembalikan beban pembuktian dapat dilakukan terhadap kepemilikan harta pelaku tindak pidana korupsi dengan menitikberatkan pada pengembalian harta negara yang dikorupsi oleh pelaku tindak pidana korupsi. ${ }^{47}$

Polarisasi pemikiran ini didasarkan pada filosofi bahwa terhadap kesalahan orang. (schuld) tidak dapat dilakukan pembalikan beban pembuktian karena melanggar prinsip "due procees of law", tetapi terhadap kepemilikan harta pelaku tindak pidana korupsi dapat diperguna kan pembalikan beban pembukti-an Keseimbangan kemungkinan (balanced probability of principles). ${ }^{48}$ Teori ini secara imperatif tetap menempatkan adanya kewajiban penuntut umum untuk membuktikan secara negatif menurut undang-undang (negatief wettelijke bewijs theorie), tentang aspek yang bersifat menyangkut status sosial terdakwa (persoon), apabila hal ini dapat dibuktikan, baru kemudian adalah kewajiban terdakwa melalui mekanisme pembalikan beban pembuktian untuk membuktikan

${ }^{46}$ Lilik Mulyadi, Asas Pembalikan Beban Pembuktian Terhadap Tindak Pidana Korupsi Dalam Sistem Hukum Pidana Indonesia Pasca Konvensi Perserikatan Bangsa-Bangsa Anti Korupsi 2003, (Bandung: Alumni, 2007),hlm. 110. Lihat juga Oliver Stolpe, Meeting the burden of proof in corruption related legal proceedings, unpublished, hlm. 2-3.

${ }^{47}$ Ibid, hlm. 111.
${ }^{48}$ Ibid, hlm. 501. 
serta menjelaskan bagaimana yang bersangkutan mampu dapat hidup dengan kekayaan yang ada, atau bagaimana kekayaannya tersebut berada di bawah kekuasaannya. ${ }^{49}$

Pelaku yang diduga telah melakukan tindak pidana korupsi tetap mempergunakan jalur pid-ana dengan pembuktian secara negatif menurut undang-undang (negatief wettelijke bewijs theorie) terhadap kesalahan (schuld) pelaku. Terhadap pengembalian harta kepemilikan pelaku tindak pidana korupsi dapat dipergunakan pembalikan beban pembuktian, karena dimensi ini relatif tidak bersinggungan dengan aspek HAM, tidak melanggar hukum acara pidana, hukum pidana materiil maupun instrumen hukum internasional. Di satu sisi, untuk membuktikan kesalahan (schuld) pelaku tindak pidana korupsi tetap berpegangan pada ketentuan teori hukum pembuktian yang tetap mengedepankan teori pembuktian secara negatif menurut undangundang (negatief wettelijke bewijs theorie). Untuk mengembalikan aset hasil dari tindak pidana korupsi, pembuktian terhadap kepemilikan harta kekayaan pelaku dilakukan dengan jalan menggunakan pembalikan beban pembuktian keseimbangan kemungkinan (balanced probability of principles).

Pembalikan beban pembuktian keseimbangan kemungkinan (balanced probability of principles) di atas, disimpulkan bahwa teori ini dapat menjadi solusi penerapan pembalikan beban pembuktian dalam Undang-Undang Pemberantasan
Tindak Pidana Korupsi.Terutama menyangkut asal usul harta kekayaan milik terdakwa. Memang tidak dapat dipungkiri bahwa eksistensi pembalikan beban pembuktian pada kete-ntuan Pasal $37 \mathrm{~A}$ dan Pasal 38 B ayat (1) dan (2) UndangUndang Pe-mberantasan Tindak Pidana Korupsi didasarkan pada tujuan pengembalian aset (asset recovery) hasil tindak pidana korupsi. Pengaturan mengenai pembalikan beban pembuktian dalam ketentuan Pasal 37 A dan Pasal 38 B Undang-Undang Pemberantasan Tindak Pidana Korupsi, belumlah sepenuhnya dapat dikatakan sudah mengacu kepada "teori pembalikan beban pembuktian Keseimbangan Ke-mungkinan (Balanced Probability of Principles)"dari Oliver Stolpe. Ketentuan Pasal 37 A ayat (2), yang mengandung arti bahwa selain terdakwa diwajibkan untuk membuktikan bahwa ia tidak melakukan tindak pidana korupsi, terdakwa juga diwajibkan memberikan keterangan tentang seluruh harta bendanya dan harta benda istri atau suami, anak, dan harta benda setiap orang atau korporasi yang diduga mempunyai hubungan dengan perkara yang didakwakan dan melakukan pembalikan beban pembuktian hanya dalam hal membuktikan tentang kekayaan yang tidak seimbang dengan penghasilannya atau sumber penambahan kekayaannya yang patut di duga diperoleh dari hasil korupsi. Hal ini berarti bahwa kepada terdakwa dibebankan untuk membuktikan 2 (dua) hal, yaitu Pertama, membuktikan unsur kesa-

$$
{ }^{49} \text { Ibid., hlm. } 150 .
$$


lahan (schuld) terdakwa, dan Kedua, melakukan pembuktian terhadap asal usul mengenai kepemilikan harta kekayaan pelaku yang diduga berasal dari tindak pidana korupsi. Menurut teori pembalikan beban pembuktian keseimbangan kem-ungkinan (balanced probability of principles), terhadap kesalahan orang (schuld) tidak dapat dilakukan pembalikan beban pembuktian, tetapi dibuktikan secara negatif menurut undang-undang (negatief wettelijke bewijs theorie) oleh penuntut umum, dan terhadap kepemilikan harta pelaku tindak pidana korupsi dapat dipergunakan atau dapat dibuktikan dengan pembalikan beban pembuktian.

Ketentuan Pasal 37 Undang-Undang Pemberantasan Tindak Pidana Korupsi, sangatlah bertolak belakang dengan prisip-prinsip yang terkandung dalam teori pembalikan beban pembuktian keseimbangan ke-mungkinan (balanced probability of principles). Ketentuan Pasal 37 Undang-Undang Pemberantasan Tindak Pidana Korupsi menyatakan bahwa terdakwa mempunyai hak untuk membuktikan bahwa ia tidak melakukan tindak pidana korupsi. Hal ini berarti bahwa dalam ketentuan Pasal 37 tersebut, terdakwa mempunyai hak untuk membuktikan unsur kesalahan (schuld) terdakwa, sementara hal tersebut tidak dibenarkan dalam teori pembalikan beban pembuktian keseimbangan kemungkinan (balanced probability of principles). Kemudian juga dalam penjelasan Pasal 37 ayat (2) Undang-Undang Pemberantasan Tindak Pidana Korupsi dikatakan secara tegas bahwa ketentuan ini tidak menganut sistem pembuktian secara negatif menurut undang-undang. Sementara itu, teori pembalikan beban pembuktian keseimbangan kemungkinan (balanced probability of principles) mengedepankan keseimbangan secara proporsional antara pembuktian secara negatif menurut undangundang (negatief wettelijke bewijs theorie) yang dilakukan oleh penuntut umum dengan pembalikan beban pembuktian yang dilakukan oleh terdakwa menyangkut asal usul harta kekayaan miliknya. Berdasarkan Pasal 12 B ayat (1) yang mengatur tentang suap dan gratifikasi, dalam ketentuan pasal tersebut terlihat jelas bahwa kepada terdakwa dibebankan untuk membuktikan, yaitu Pertama, membuktikan unsur kesalahan (schuld) ter-dakwa menyangkut delik suap, dan Kedua, melakukan pem-buktian terhadap gratifikasi tersebut bukan merupakan suap. Hal seperti di jelaskan di atas mengenai pembuktian pertama yang dilakukan oleh terdakwa, juga tidak dibenarkan dalam teori pembalikan beban pembuktian keseimbangan kemungkinan (balanced probability of principles). Ketentuan Pasal $12 \mathrm{~B}$ ayat (1) huruf a, merupakan penerapan pembalikan beban pembuktian secara murni, yang tidak memberi ruang bagi penuntut umum untuk membuktikan secara negatif menurut undang-undang (negatief wettelijke bewijs theorie). Kebijakan legislasi yang diharapkan lahir dari suatu ke-bijakan dalam hukum pidana, dalam bentuk pengaturan mengenai "teori pembalikan beban pembuktian keseimbangan kemungkinan (balanced probability of principles)"yang 
seharusnya diadopsikan kedalam Undang-Undang Pemberantasan Tindak Pidana Korupsi, diharapkan dapat menjadi penyeimbang secara proporsional antara kewenangan penuntut umum dalam membuktikan secara negatif menurut undangundang (negatief wettelijke bewijs theorie) dengan kepentingan terdakwa dalam hal membuktikan asal-usul harta yang dimilikinya dan juga diharapkan menjadi sarana atau alat untuk mengembalikan aset negara yang dikorupsi. Dengan demikian "teori pembalikan beban pembuktian keseimbangan kemungkinan (balanced probability of principles)" dari Oliver Stolpe dapat menjadi justifikasi teoritis untuk menerapkan pembalikan beban pembuktian.

Pembalikan beban pembuktian saat proses persidangan berlangsung, terdakwa juga dibebankan melakukan pembuktian mengenai unsur "menerima hadiah atau janji padahal diketahui atau patut diduga bahwa hadiah atau janji tersebut diberikan untuk mempengaruhi putusan perkara yang diserahkan kepadanya untuk diadili" dan unsur "menerima hadiah atau janji padahal diketahui atau patut diduga bahwa hadiah atau janji tersebut diberikan karena kekuasaan atau kewenangan yang ada hubungannya dengan jabatannya (in zijn bedeming)".

Unsur-unsur yang harus dibuk. tikan secara esensial merupakan pembuktian unsur-unsur yang terkait langsung dengan pembuktian kesalahan (schuld) dari terdakwa. Dengan dilakukannya pembalikan beban pembuktian terhadap unsur kesalahan (schuld) dari terdakwa dalam perkara ini, dengan sudut pandangan yang netral haruslah kita akui bahwa hal tersebut menyebabkan beralihnya asas praduga tidak bersalah (presumption ofinnocent) menjadi asas praduga bersalah (presumption of guilt) dan relatif cenderung dianggap sebagai pengingkaran terhadap asas-asas yang telah berlaku secara universal. Dalam hal ini tidak bisa dipungkiri bahwa telah terjadi akses negatif dari pembalikan beban pembuktian karena pembalikan beban pembuktian tersebut ditujukan terhadap pembuktian kesalahan (schuld) dari terdakwa. Dengan mengedepankan keseimbangan secara proporsional antara perlindungan kemerdekaan individu di satu sisi, dan perampasan hak individu yang bersangkutan atas harta kekayaan milik pelaku yang yang diduga kuat berasal dari korupsi disisi lainnya.

Suatu pembalikan beban pembuktian terdakwa harus dapat membuktikan secara berlawanan unsurunsur yang disangkakan terhadap terdakwa dengan menggunakan standar minimal 2 (dua) alat bukti sebagaimana yang dikehendaki oleh Pasal 183 KUHAP. Memang hal ini sudah di muat dalam ketentuan Pasal 26 A Undang-Undang Pemberantasan Tindak Pidana Korupsi, hanya saja pengaturan mengenai hal ini masih belum lengkap dan memadai. Dikatakan demikian karena ketentuan Undang-Undang Pemberantasan Tindak Pidana Korupsi tidak mengatur secara tegas menyangkut hal-hal apa saja yang harus dibuktikan, ins-trumen apa saja yang dapat dijadikan sebagai alat bukti oleh terdakwa, dan sampai sejauh mana kewenangan dan 
batasan-batasan yang diberikan pada terdakwa dalam hal melakukan pembuktian. Tidak dimuatnya hal tersebut dalam ketentuan Undang-Undang Pemberantasan Tindak Pidana Korupsi, mengakibatkan terdakwa tidak mempunyai acuan yang jelas dan tegas dalam melakukan pembuktian, hal tersebut akan merugikan terdakwa dan akan berpengaruh pada kualitas pembuktian yang dilakukan oleh terdakwa sendiri.

Pembalikan beban pembuktian memakai standar minimal 2 (dua) alat bukti sebagai mana yang dikehendaki oleh Pasal 183 KUHAP, namun tidaklah bisa disamaratakan antara perkara yang satu dengan perkara lainnya dan juga tidak bisa disamaratakan menyangkut kemampuan dan pengetahuan hukum antara terdakwa yang satu dengan terdakwa lainnya. Dari itu hendaklah hal tersebut dimuat dalam ketentuan Undang-Undang Pemberantasan Tindak Pidana Korupsi.

Pembalikan beban pem-buktian yang dimuat dalam ketentuan Undang-Undang Pemberantasan Tindak Pidana Korupsi yang berlaku saat ini, hanya mengatur bahwa apabila terdakwa berhasil membuktikan bahwa apa yang diterimanya bukan merupakan suatu gratif-ikasi, atau penerimaan itu tidak ada hubungannya dengan jabatan atau kedudukannya atau dengan kewajiban atau tugasnya, maka sesungguhnya sama artinya dengan terdakwa telah berhasil membuktikan bahwa dirinya tidak terbukti menerima gratifikasi yang dianggap berasal dari pemberian suap. Meskipun pada dasarnya, mengenai status te- lah berhasil atau tidak berhasilnya suatu pembalikan beban pembuktiaan yang dilakukan terdakwa beserta penasehat hukumnya tetap pada Majelis Hakim. Namun tidaklah adil rasanya bagi terdakwa, apabila Undang-Undang Pemberantasan Tindak Pidana Korupsi tidak mengatur tentang apa yang dijadikan parameter oleh hakim untuk dapat menyatakan berhasil atau tidaknya pembuktian yang dilakukan oleh terdakwa tersebut. Atau dengan kata lain harusnya ada pengaturan yang jelas dan tegas mengenai tolak ukur tentang berhasil atau tidaknya pembalikan beban pembuktian yang dilakukan oleh terdakwa.Ketentuan UndangUndang Nomor 31 Tahun 1999 jo Un-dang-Undang Nomor 20 Tahun 2001 tentang Pemberantasan Tindak Pidana Korupsi tidak mengatur secara jelas dan tegas mengenai pada saat kapan penerapan pembalikan beban pembuktian atau dengan kata lain, pada agenda sidang yang manakah dilaksanakan diterapkan pembalikan beban pembuktian tersebut. Ditambah lagi dengan adanya perbedaan ketentuan Pasal 38 A dengan ketentuan Pasal $38 \mathrm{~B}$ ayat (4). Ketentuan Pasal $38 \mathrm{~A}$ mengatur bahwa: "Pembuktian sebagai-mana dimaksud Pasal $12 \mathrm{~B}$ ayat (1) dilakukan pada saat pemeriksaan di sidang pengadilan." Dalam ketentuan pasal ini tid-aklah disebutkan secara tegas, dalam agenda sidang apa dilaksanakan penerapan pembalikan beban pembuktian tersebut. Sementara ketentuan Pasal 38 B ayat (4) menyebutkan: "Pembuktian bahwa harta benda sebagaimana dimaksud dalam ayat (1) bukan berasal dari tindak 
pidana korupsi diajukan oleh terdakwa pada saat membacakan pembelaannya dalam perkara pokok dan dapat diulangi pada memori banding dan memori kasasi.

Namun, tidak bisa dipungkiri pula dengan adanya perbedaan pendapat dan perbedaan pemahaman antara para ahli hukum dan para penegak hukum terutama kalangan hakim di Indonesia yang masih menganggap bahwa pembalikan beban pembuktian melanggar asas praduga tak bersalah ( $p r-$ esumption of innocence), akan mempersulit penerapan pembalikan beban pembuktian dalam sistem peradilan pidana di Indonesia. Bila dikaji dari perspektif kebijakan hukum pidana, eksistensi pembalikan beban pembuktian seharusnya men-gandung prevensi khusus bagi tindak pidana korupsi yang dikategorikan sebagai extra ordinary crime yang juga membutuhkan extra ordinary enforcement dan extra ordinary measures.

\section{Simpulan}

1. Urgensi penerapan pembalikan beban menjadi sangat urgen untuk diterapkan dalam rangka mengungkap kebenaran menyangkut harta-harta terdakwa kasus korupsi yang patut diduga diperoleh dari hasil korupsi yang merugikan keuangan negara, untuk mempermudah pembuktian karena motif dan modus operandi tindak pidana korupsi semakin canggih dan kompleks.

2. Pengaturan mengenai pembalikan beban pembuktian dalam Undang-Undang Pemberantasan Tindak Pidana Ko- rupsi telah mampu mendukung upaya penanggulangan korupsi di negeri ini, hanya saja masih terdapat kelemahan, sehingga ketentuan Undang-Undang Pemberantasan Tindak Pidana Korupsi harus diperbarui dengan segera. Kelemahan tersebut antara lain mengenai pengaturan pembalikan beban pembuktian dalam Undang-Undang Pemberantasan Tindak Pidana Korupsi yang bersifat terbatas atau berimbang, dalam hal ini terdakwa juga dibebankan melakukan pembuktian mengenai unsur-unsur kesalahan (schuld) dari terdakwa. Dengan sudut pandangan yang netral, haruslah diakui bahwa hal tersebut menyebabkan beralihnya asas praduga tidak bersalah (presumption ofinnocent) menjadi asas praduga bersalah (presumption of guilt) dan relatif cenderung dianggap sebagai pengingkaran terhadap asasasas yang telah berlaku secara universal. Dalam hal ini tidak bisa dipungkiri bahwa telah terjadi akses negatif dari pembalikan beban pembuktian karena pembalikan beban pembuktian tersebut ditujukan terhadap pembuktian kesalahan (schuld) dari terdakwa.

\section{Saran}

1. Sudah seharusnya penerpan pembalikan beban pembuktian mendapatkan prioritas utama dalam upaya pemberantasan korupsi. Pembalikan beban pembuktian menjadi 
sangat urgen untuk diterapkan dalam rangka mengungkap kebenaran menyangkut hartaharta terdakwa kasus korupsi yang patut diduga diperoleh dari hasil korupsi yang merugikan keuangan negara.

2. Perlu adanya suatu formula yang tepat dalam pengaturannya, baik dari perspektif teoritis, yuridis, filosofis dan praktik mengenai bagaimana pembalikan beban pembuktian ini dapat diterapkan, baik ditataran kebijakan hukum pidana, kebijakan legislasi maupun aplikasi. Hal ini didasarkan pada pola pikir bahwa pembalikan beban pembuktian haruslah dicarikan justifikasi teoritis dalam penerapannya dengan tetap berpegang teguh kepada asas-asas universal hukum acara pi-dana.

\section{Referensi}

A. Djoko Sumaryanto. 2009. Pembalikan Beban Pembuktian Tindak Pidana Korupsi dalam Rangka Pengembalian Kerugian Keuangan Negara. Jakarta : Prestasi Pustakaraya.

Achmad Ali. 2008. Menjelajahi Kajian Empiris Terhadap Hukum. Jakarta: Yasrif Watampone.

Albert Hasibuan. 1985. Guru Besar Berbicara tentang Hukum. Bandung: Alumni.

Alpiner Sinaga. 2005. Korupsi, Bias dan Strategi Penyidikan, Markas Besar Kepolisian Negara Republik Indo-nesia.
Andi Hamzah. 2008. Perbandingan Pemberantasan Korupsi di Berbagai Negara. Jakarta: Sinar Grafika.

Bambang Waluyo. 2002. Penelitian Hukum dalam Praktik. Jakarta: Sinar Grafika.

Barda Nawawi Arief. 2005. Pembaharuan Hukum Pidana Dalam Perspektif Kajian Perba-ndingan. Bandung: Citra Aditya Bakti.

Denny Indrayana. 2008. Negeri Para Mafioso : Hukum di Sarang Penyamun. Jakarta: Kompas.

Elwi Danil. Fungsionalisasi Hukum Pidana dalam Penanggulangan Tindak Pidana Korupsi, Studi Tentang Urgensi Pembaharuan Hukum Pidana Terh-adap Tindak Pidana Korupsi di Indonesia. Disertasi. Program Pascasarjana Fakultas Hukum Universitas In-donesia. Jakarta. 20-01. 2012. Korupsi: Konsep, Tindak Piana, dan Pemberantasan

nya. Jakarta: Raja grafindo Persada. Ermansjah Djaja. 2010. Tipologi Tindak Pidana Korupsi di Indonesia. Badung: Mandar Maju.

Feri Wibisono. Menyongsong Era Baru Pemberantasan Tindak Pidana Koupsi. Media Hukum. Volume 1. Nomor 2. 2002.

Indriyanto Seno Adj. 2009. Korupsi Kebijakan Aparatur Negara \& Hukum Pidana. Jakarta: Diadit Media. 
Komisi Pemberantasan Korupsi. 2008. Buku I Rencana Stratejik KPK 2008-2011. Jakarta.

Lilik Mulyadi. 2007. Asas Pembalikan Beban Pembuktian Terhadap Tindak Pidana Korupsi Dalam Sistem Hukum Pidana Indonesia Pasca Konvensi Perserikatan Bangsa-Bangsa Anti Korupsi 2003.Bandung: Alumni. 2007. Tindak Pidana Korupsi di Indonesia Normatif, Teoretis, Praktik dan Masalah-nya. Bandung: Alu-mni.

Maria Silvya E. Wangga. Mekanisme Pembalikan Beban Pembuktian Tindak Pidana Pencucian Uang Adil. Jurnal Jurnal Hukum. Volume 3. Nomor 2. 2015.

Mohammad Zamroni. Telaah Progresif: Implementasi Asas Pembuktian Terbalik (ReversedOnu-s) Terhadap Tindak Pidana Korupsi. Jurnal Legislasi Indonesia. Volume 8. Nomor 2. Juni 2011.

Mulyanto. 2016.

Praktik Pembatasan Pembalikan Beban Pembuktian Dalam Pengadilan Tipikor (Studi Pada Perkara Korupsi RAPBD Kota Semarang di Pengadilan Tipikor Kota Semarang). JurnalJu-risprudence. Volume 6. Nomor 2. Sep-tember 2016.

O.S Hiariej. 2009. Asas Legalitas dan Penemuan Hukum Dalam Hukum Pidana. Jakarta: Erlangga.
Romli Atmasasmita. 2002. Korupsi, Good Governance dan Komisi Anti Korupsi di Indonesia, Jakarta: Badan Pembinaan Hukum Nasional Departemen Kehakiman dan HAM RI.

2004. Sekitar Masalah Korupsi Aspek Nasional dan Aspek Internasional. Bandung: Mandar Maju.

2004.Sekitar

Masalah Korupsi Aspek Nasional dan Aspek Internasional. Bandung: Mandar Maju.

Soerjono Soekanto. 2006. Pengantar Penelitian Hukum, Penerbit Universitas Indonesia. Jakarta: UIPress.

Soerjono Soekanto dan Sri Mamudji. 2009. Penelitian Hukum Normatif (Suatu Tinjauan Singkat). Jakarta: Raja Grafindo Persada.

Saldi Isra.Pemberantasan Korupsi: Beberapa Warisan Islam Yyang Dipraktikkan di Indonesia.Jurnal Kons-titusi. Pusako Univer-sitas Andalas. Volume III. Nomor 2. 2010.

Sudikno Mertokusumo dan A. Pitlo. 1993. Bab-bab Tentang Penemuan Hukum. Bandung: Citra Aditya Bakti.

Sudarto. 1986. Hukum dan Hukum Pidana. Bandung: Alumni.

Wahyu Wiriadinata. 2012. Korupsi dan Pembalikan Beban Pembuktian. Jurnal Konstitusi. Volume 9. Nomor 2. Juni 201 